\title{
ROBOT PENCARI BENDA MENGGUNAKAN PERINTAH SUARA BERBASIS ARDUINO UNO
}

\author{
Ilamsyah $^{1}$, Hendri Iksan Setyawan ${ }^{2}$, Alfianti Syahfitri ${ }^{3}$ \\ Dosen STMIK Raharja Tangerang ${ }^{1,2}$, Mahasiswa STMIK Raharja ${ }^{3}$ \\ J1. Jendral Sudirman No. 40, Modernland, Tangerang ${ }^{1,2,3}$ \\ e-mail: ilamsyah@raharja.info ${ }^{1}$,hendri@raharja.info ${ }^{2}$, alfianti@raharja.info ${ }^{3}$
}

\begin{abstract}
Abstrak
Kemajuan bidang komputerisasi yang tinggi umumnya pada bidang mikrokontroler semakin hari semakin meningkat khusunya pada masyarakat. Penelitian ini bertujuan untuk mengetahui kelayakan sebuah teknologi dengan menggunakan media robot pencari benda yang berguna bagi masyarakat. Penelitian ini menggunakan pendekatan penelitian pengembangan dan dilanjutkan dengan penelitian tindakan observasi. Penelitian ini menggunakan metode color filtering RGB yang dimana sebuah sensor memilih sesuai warna yang ingin di cari dan activate sound untuk menggerakan sebuah robot. Pengolahan data penelitian dilakukan secara deskriptif kuantitatif. dalam bidang komputer yang memiliki peranan sangat penting dalam dunia teknologi informasi dan berfungsi sebagai media yang dapat mengolah kreatifitas, dan imajinasi menjadi bentuk yang nyata, maka dirancanglah sebuah robot pencari benda menggunakan perintah suara berbasis arduino uno yang mempunyai kecerdasan untuk membantu manusia yang lupa menaruh sebuah benda. Menggunakan sensor-sensor yang tersedia, yaitu sensor cahaya warna untuk mendeteksi benda, menggunakan sensor ultrasonic untuk menghindari tabrakan robot dengan benda. Dilengkapi aplikasi desktop untuk menampilkan jarak lokasi benda yang ditentukan dengan skala putaran roda. Koneksi menggunakan bluetooth. sebagai robot untuk membantu manusia dalam hal menemukan sebuah benda. untuk pembangunan robot dengan menggunakan beberapa motor dan juga sensor. Namun daya pemrosesan, memori, dan kemampuan komunikasi tidak jauh berbeda denga robot-robot lainnya yang menggunakan perangkat PDA atau laptop. Sistem robot ini menggunakan ARM voice yang di control menggunakan smartphone, sehingga robot ini lebih efektif digunakan, dan berguna guna membantu pekerjaan.
\end{abstract}

Kata kunci: Robot, Benda, Suara, Arduino, Smartphone

\begin{abstract}
The progress of the computerized field is generally high in the field of microcontrollers are increasingly increasing especially in the community. This study aims to determine the feasibility of a technology by using media robot search objects that are useful for the community. This research uses development research approach and continued with research of observation action. This research uses RGB color filtering method where a sensor chooses according to the color you want to search and activate sound to move a robot. Data processing research conducted by descriptive quantitative. In the field of computers that have a very important role in the world of information technology and serves as a medium that can process creativity, and imagination into a real form, then designed an object-finding robot using arduino uno-based voice command that has the intelligence to help people forget to put a object. Using available sensors, ie light-colored sensors to detect objects, use ultrasonic sensors to avoid robotic collisions with objects. Equipped with a desktop application to display the distance of a specified object with a wheel spin scale. Connect using bluetooth. As a robot to help humans in terms of finding an object. For the construction of robots using multiple motors and sensors. But the processing power, memory, and communication capabilities are not much different from other robots that use PDA or laptop devices. This robot system uses ARM voice in control using a smartphone, so the robot is more effective to use, and useful to help the job.
\end{abstract}

Keywords: Robot, Objects, Sound, Arduino, Smartphone 


\section{PENDAHULUAN}

Teknologi robot sebagai alat bantu manusia terus berkembang sekarang ini untuk menjawab tantangan itu. Mulai dari tujuan hiburan, robot mobil cerdas, alat pengangkut barang, hingga misi luar angkasa telah menggunakan teknologi robot. Robot diciptakan sebagai alat bantu manusia. Dengan melihat peran robot yang semakin besar, dituntut adanya metodemetode baru untuk penyempurnaan teknologi robot mobil ini. Pada robot mobil, terutama yang memiliki misi "menuju sasaran" dengan tipe penggerak differensial biasanya hanya terdapat satu kontroler close loop untuk mengendalikan posisi robot. Sedangkan kendali kecepatan ke roda kanan dan kiri untuk mengatur pergerakan robot dilakukan secara open loop atau dengan kata lain kecepatan roda aktual tidak di perhatikan. Mengingat banyak sekali hal yang mempengaruhi kecepatan putar roda seperti tidak identiknya kinerja kedua roda, berat robot dan lintasan robot yang berupa tanjakan atau turunan, membuat metode pengendalian kecepatan secara open loop ini sangat merugikan.Apalagi di zaman modern sekarang ini, semua sudah serba instan dan canggih, dikarenakan tuntutan hidup yg terjadi semua manusia ingin semuanya serba praktis dan serba instan, dan di era modern seperti ini kemajuan pada pola pemikiran manusia seperti sekarang sudah banyak penemuan penemuan yang sangat Kreatif dan Inovatif, bagaimana tidak dalam satu harinya saja sudah ada hampir 1 sampai 5 alat dan penemuanya yang di ciptakan setiap harinya. Dan untuk mengikuti persaingan dan persaingan yg ada di masyarakat kita di tuntut untuk memberikan inovasi penemuan yang dapat membantu kehidupan manusia sekarang.

Dalam penelitian ini peneliti menggunakan input voice sebagai penggerak robot yang berbasis arduino uno dengan output motor $D C$, sensor warna serta notifikasi lampu LED. Robot ini dirancang menyerupai mobil beroda empat yang dilengkapi komponen berupa arduino uno , sensor warna, motor driver L293, sensor bluetooth, ultrasonic dan smartphone yang dijadikan sebagai perintah untuk menjalankan robot pencari benda tersebut.

\subsection{Permasalahan}

Dalam dunia sehari benda adalah yang sering kita pakai, jika terjadi sesuatu terhadap benda atau barang yang di perlukan hilang maupun lupa menaruhnya, hal itu akan merepotkan sekali, apalagi manusia tidak luput dari lupa. Padahal benda tersebut itu penting dan berharga oleh sebuah instansi atau perusahaan karena dalam sebuah ruangan banyak tersimpan barangbarang penting, yang jika hilang akan merugikan diri sendiri, maupun instansi/perusahaan tersebut. Pada permasalahan ini terdapat banyak celah diantaranya:

1. Hilangnya benda atau barang yang mungkin sebagian orang sulit menemukannya, apalagi jika benda tersebut terlalu kecil atau samar-samar.

2. Kecerobohan pemilik benda yang tidak bisa menjaga bendanya, memungkinkan benda tersebut lupa menaruh apalagi jika benda tersebut terselip di suatu tempat, kemungkinan beberapa persen orang dapat menemukan benda tersebut.

3. Kelengkapan alat bantu untuk mencari suatu benda masih kurang.

4. Dibutuhkan metode pembelajaran yang dapat mendorong seseorang untuk mengaplikasikan pengetahuannya tentang robot vision.

Sistem yang lebih canggih dan modern untuk menemukan sebuah benda sangat dibutuhkan dan perlu diterapkan dalam instansi/perusahaan untuk membantu pegawai kepada pemilik benda atau barang untuk mencari sebuah benda yang hilang, maka di perlukan robot pencari benda menggunakan perintah suara dengan pengontrolan melalui smartphone.

\section{LANDASAN TEORI}

\subsection{Literature Review}

Banyak penelitian yang sebelumnya dilakukan mengenai robot pencari benda menggunakan perintah suara berbasis arduino uno. Dalam upaya mengembangkan dan menyempurnakan robot ini perlu dilakukan studi pustaka (literature review) sebagai salah satu 
dari penerapan metode penelitian yang akan dilakukan. Diantaranya adalah mengidentifikasikan kesenjangan, menghindari pembuatan ulang, mengidentifikasikan metode yang pernah dilakukan, meneruskan penelitian sebelumnya, serta mengetahui orang lain yang spesialisasi dan area penelitiannya sama dibidang ini. Beberapa Literature review tersebut adalah sebagai berikut:

1. Penelitian ini dilakukan oleh Roni Setiawan dari Fakultas Teknik Universitas Negeri Yogyakarta pada tahun 2012 yang berjudul "Robot Pendeteksi Objek Berdasarkan Warna Dengan Sensor Kamera Sebagai Media Pembelajaran”. Program studi teknik mekatronika merupakan program studi yang mempelajari sistem otomasi dan robotika. Sistem otomasi merupakan bidang pengetahuan yang mempelajari tentang perpaduan antara kerja hardware dan software, sehingga akan terbentuk suatu mesin atau sistem yang multifungsi yang dapat digunakan untuk mempermudah kegiatan manusia. Robotika merupakan bidang ilmu yang mempelajari tentang struktur dan prinsip kerja dari robot, mulai dari sensor robot, mekanik robot dan otak robot. Kemajuan teknologi terus berkembang pesat sampai di berbagai bidang. Kemajuan teknologi yang sedang berkembang saat ini identik dengan perkembangan teknologi otomasi dan robotika. Oleh karena itu, program studi teknik mekatronika menjadi salah satu program studi yang harus dikembangkan secara penuh demi mengikuti perkembangan teknologi dunia.

2. Penelitian yang dilakukan oleh Rendy Dartha Nugraha dari Fakultas Teknologi Informasi Universitas Andalas yang berjudul "Rancang Bangun Mobile Robot Pengikut Manusia Berdasakan Warna Menggunakan Metode Template Matching Berbasis Mini PC" Jurnal Nasional Sains dan Teknologi 2016 p-ISSN : 2407 - 1846. Sistem visual buatan atau vision system (computer vision) adalah suatu sistem yang mempunyai kemampuan untuk menganalisis objek secara visual, setelah data objek yang bersangkutan dimasukkan dalam bentuk citra. Disiplin ilmu yang melahirkan teknik-teknik untuk pengolahan citra ini dinamakan pengolahan citra digital. Robot pengikut manusia merupakan salah satu implementasi dari pengolahan citra digital dimana robot harus dapat mengenali objek.

3. Penelitian ini dilakukan oleh Anis Zaenal Abidin dari Universitas Diponegoro Semarang pada tahun 2011 yang berjudul "Pengendalian Robot Mobil Pencari Target Dan Penghindar Rintangan Dengan Metode Kontrol PD Menggunakan Mikrokontroler AVR Atmega 8535". Robotika merupakan bidang ilmu pengetahuan yang mengalami perkembangan dengan cepat, salah satunya adalah Wheeled Mobile Robot (WMR). Pembahasan mengenai robot mobil meliputi banyak hal seperti fungsi dan kegunaannya, sistem navigasinya, metode kontrol yang digunakan dan lain-lain. Sedangkan contoh aplikasinya dalam kehidupan sehari-hari meliputi robot pembersih ruangan, penjinak bom, kursi roda cerdas (Smart Wheel Chair), Self Parking Car (SPC), hingga penghantar barang di pabrik-pabrik ataupun rumah sakit. Untuk sistem navigasi robot mobil, banyak peneliti yang telah mengembangkan robot mobil beroda yang dapat melakukan navigasi tanpa garis sebagai guidance dengan menghitung posisi dan orientasinya berdasarkan informasi putaran rodanya yang biasa dikenal dengan istilah dead reckoning.

4. Penelitian ini dilakukan oleh Siti Nurmaini dari Sriwijaya University, Volume 2 No. 3, March 2012 ISSN 2223-4985yang berjudul "Modeling of Mobile Robot System with Control Strategy Based on Type-2 Fuzzy Logic". Controlling a mobile robot to navigate autonomously in real world environments is a challenging and difficult task. Due to there are large amount of uncertainties and imprecisions present in such environments [1-3]. Uncertain environment will give information's to the sensors and lead to various behavior by the mobile robot. The ability to navigate is obviously a major requirement for a mobile robot to survive in a given environment or to fulfill its mission to reach the goal.

5. Penelitian ini dilakukan oleh Agung Alpurqon dari STMIK Raharja pada tahun 2014 yang berjudul "Sistem Pengendali Pintu Pagar Secara Otomatis Menggunakan Aplikasi Voice Command Pada Smartphone Android OS". Android merupakan teknologi canggih yang menjadi daya tarik orang lain untuk menggunakannya. Peneliti menggunakan input suara untuk mengontrol buka dan tutup pintu pagar, dengan android sebagai media input 
dalam sebuah smartphone. Peneliti merancang sebuah sistem kontrol pintu pagar menggunakan rangkaian mikrokontroler yang diprogram menggunakan bahasa program terperinci.

6. Penelitian ini dilakukan oleh Gogor C. Setyawan dari Universitas Kristen Immanuel,Fakultas Sains dan Komputer pada tahun 2015 yang berjudul "Sistem Robot Otonom Penghindar Rintangan dan Pencari Jalur Menuju Sasaran Berbasis Mikrokontroler PIC16F877A". Robot bergerak pada lingkungan bidang datar. Pada bidang datar tersebut terdapat rintangan dan sasaran. Untuk mencapai sasaran robot dipandu oleh penjejak sinyal ultrasonik. Untuk menghindari benda perintang robot dipandu oleh sinyal inframerah.

7. Penelitian ini dilakukan oleh Yustinus Pancasila Prayitno dari STIKOM Surabaya, Jurusan Sistem Komputer pada tahun 2012 yang berjudul "Rancang Bangun Bentuk Aplikasi Pendeteksi Bentuk Dan Warna Benda Pada Mobile Robot Berbasis Webcam". Robot ini terintegrasi dengan sebuah webcam dengan interface USB yang dapat mendeteksi garis yang biasa digunakan sebagai line tracer. Pemanfaatan webcam ini dapat dikembangkan sehingga dapat digunakan sebagai sensor dalam mendeteksi sebuah benda melalui beberapa tahap pengolahan citra. Webcam dimanfaatkan sebagai indra penglihatan dalam robot yang dapat digunakan untuk menangkap gambar dan kemudian gambar tersebut akan diolah untuk menentukan objek yang dideteksi.

8. Penelitian ini dilakukan oleh Ratnasari Nur Rohmah dari Universitas Muhammadiyah Surakarta pada tahun 2016 yang berjudul "Rancang Bangun Robot Beroda dengan Object Tracking Sebagai Dasar Pengendalian Gerakan Robot". Robot beroda dengan metode object tracking sebagai pengendali gerakan robot. Object tracking dilakukan dengan mengenali obyek yang akan diikuti, mengukur beberapa parameter obyek yang akan dijadikan dasar pengendalian, dan mengatur gerakan obyek berdasar analisa parameter yang terukur.

9. Penelitian ini dilakukan oleh Fajar Timang Patiung dari Jurusan Teknik Elektro-FT, UNSRAT pada tahun 2013 yang berjudul "Rancang Bangun Robot Beroda dengan Pengendali Suara". Salah satu jenis robot dengan kemampuan istimewa yang menarik untuk dikembangkan adalah robot beroda dengan pengendali suara yang memanfaatkan teknologi pengenalan suara sebagai penggerak motor DC. Perancangan robot beroda dengan pengendali suara ini menggunakan Arduino UNO R3 sebagai pengontrol, modul Easy Voice Recognition, Motor Driver sebagai pengendali motor DC, dan untuk mekaniknya menggunakan sistem roda dengan motor DC sebagai aktuatornya.

10. Penelitian ini dilakukan oleh Rudy Dikairono dari Institut Teknologi Sepuluh Nopember (ITS) Surabaya, Indonesia pada tahun 2013 yang berjudul "Sistem Navigasi Dan Penghindar Rintangan Pada Mobile Robot Menggunakan GPS Dan Pengukur Jarak Ultrasonik". Implementasi dari sistem yang dibuat menghasilkan mobile robot yang dapat bergerak secara otomatis menuju titik yang telah ditentukan oleh user. Data kontrol kemudi yang diberikan adalah belok kanan, belok kiri dan maju lurus dengan dua level kecepatan yakni lambat dan cepat.

\section{HASIL DAN PEMBAHASAN}

Setelah melakukan pengamatan dan penelitian dari beberapa permasalahan yang dihadapi, maka diberikan alternatif pemecahan masalah yang sekiranya dapat membantu user dalam menjalankan robot tersebut. Alternatif pemecahan masalah sebagai berikut :

1. Merancang sebuah robot pencari benda dengan pengendalian smartphone yang di hubungkan dengan arduino uno yang mampu mengendalikan robot pencari benda tersebut pada sebuah ruangan.

2. Robot pencari benda yang dirancang berfungsi untuk mencari suatu benda sehingga dapat membantu si pengguna untuk mempermudah menemukan suatu benda. 


\subsection{Metode Penelitian}

Pada saat ini terdapat banyak metodelogi dalam pembangunan sistem. Salah satu metodelogi yang digunakan dalam penelitian ini adalah metode prototype. Secara umum pembangunan sistem pada model prototype terdapat tahapan-tahapan sebagai berikut :

\section{a. Metode Analisa Kebutuhan}

Metode ini melakukan analisa suatu kebutuhan, bagaimana sistem itu berjalan dan apakah kekurangan dari alat tersebut. Benda merupakan sebuah barang yang di miliki setiap manusia dan bagaimana jika hilang atau lupa menaruh. Sehingga perlu di buatnya sebuah alat untuk membantu manusia dalam menemukan sebuah barang.

\section{b. Metode Perancangan Sistem}

Metode ini dimaksudkan untuk menghasilkan suatu rangkaian alat yang tepat sehingga diperoleh hasil rancangan yang sesuai dengan yang diinginkan. Melalui tahapan pembuatan flowchart dari sistem yang akan dibuat dan pembuatan desain aplikasi pengontrolan berupa perancangan perangkat lunak (software) dan perangkat keras (Hardware).

Mikrokontroler pertama kali dikenalkan oleh texas intrument dengan seri TM S 1000 pada tahun 1974 yang merupakan mikrokontroler 4 bit pertama. Mikrokontroler ini mulai dibuat sejak 1971 merupakan mikrokomputer dalam sebuah chip, lengkap dengan RAM dan ROM. Kemudian, pada tahun 1976 intel mengeluarkan mikrokontroler yang kelak menjadi populer dengan nama 8748 yang merupakan mikrokontroler 8 bit, yang merupakan mikrokontroler dari keluarga MCS 48. sekarang dipasaran banyak sekali ditemui mikrokontroler mulai dari 8 bit sampai dengan 64 biit, sehingga perbedaan antara mikrokontroler dan mikroprosesor sangat tipis. Masing-masing vendor mengeluarkan mikrokontroler dengan dilengkapi fasilitas yang cendrung memudahkan user untuk merancang sebuah sistem dengan komponen luar yang relatif lebih sedikit. Saat ini mikrokontroler yang banyak beredar dipasaran adalah mikrokontroler 8 bit carian keluarga MCS51 (CISC) yang dikeluarkan oleh Atmel dan seri AT89Sxx dan mikrokontroler AVR yang merupakan varian dari mikrokontroler RISC dengan seri ATMEGA8535 (walaupun varian dari mikrokontroler AVR sangatlah banyak, dengan masingmasing memiliki fitur yang berbeda-beda). Dengan mikrokontroler tersebut pengguna (pemula) sudah bisa membuat sebuah sistem untuk keperluan sehari-hari, seperti pengendali peralatan rumah tangga jarak jauh yang menggunakan remote control televisi, radio frekuensi, maupun menggunakan ponsel, membuat jam tangan digital, termometer digital, dan sebagainya.

Robot Pencari Benda tersebut. Adapun diagram sistem blok secara keseluruhan ditunjukkan pada gambar 1:

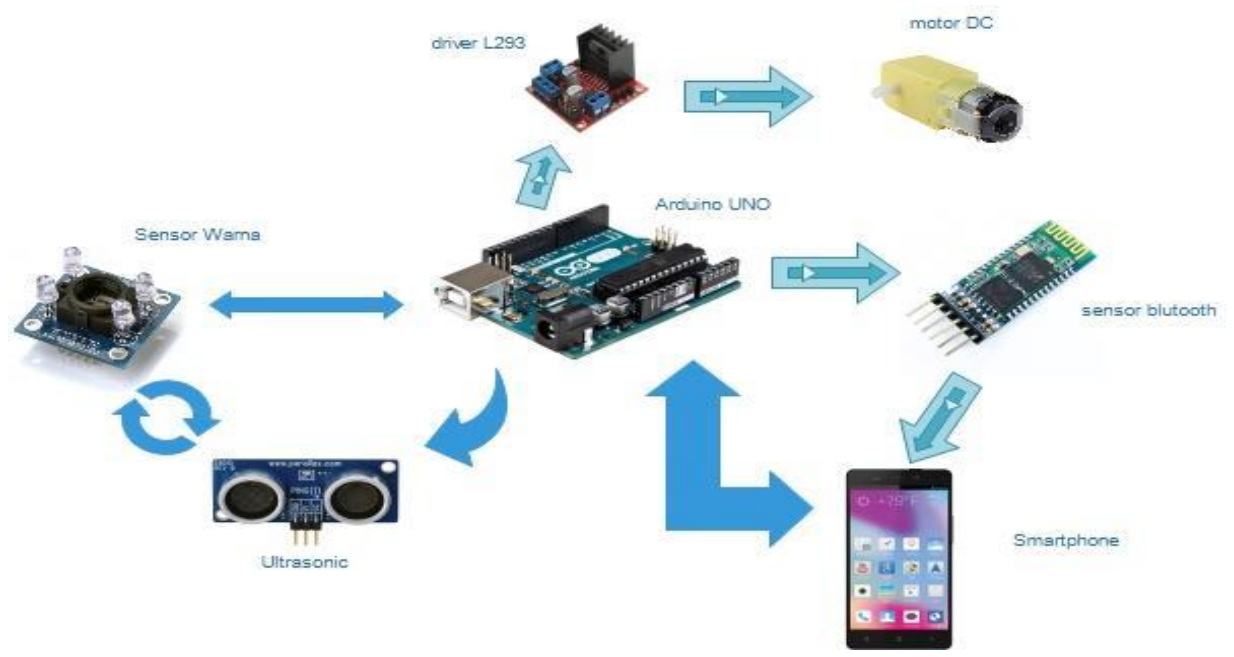

Gambar 1. Diagram Blok Rangkaian 


\subsection{Flowchart Sistem}

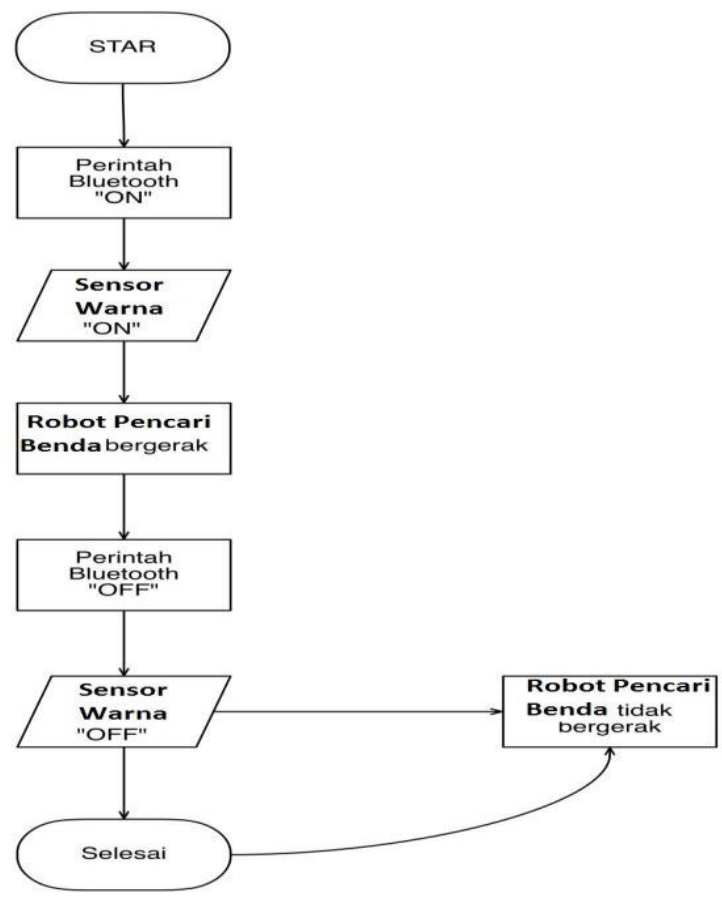

Gambar 2. Flowchart Sistem

Sistem diawali dengan start yang berarti sistem akan mulai bekerja, kemudian user menyalakan bluetooth smartphone agar bisa terkoneksi pada bluetooth robot. Jika bluetooth sudah terkoneksi maka lampu led akan menyala yang menandakan antara robot dengan smartphone sudah terhubung. Sebaliknya jika bluetooth tidak terkoneksi maka lampu led tidak menyala dan robot tidak akan berjalan.

Arduino uno yang di pasangi sensor warna, yang terinput oleh voice melalui smartphone tadi, sehingga data diolah dan memproses perintah yang akan dikerjakan oleh robot, robot otomatis berjalan dan mencari benda yang dimaksud. Bila input voice pada smartphone untuk mencari suatu benda maka led akan otomatis mati, dan jika benda sudah ditemukan maka lampu led akan otomatis menyala.

\subsection{Perancangan Hardware}

Pada perancangan di sini yang dimaksudkan meliputi perancangan perangkat keras (hardware) dan perangkat lunak (software). Perancangan sistem secara keseluruhan memerlukan beberapa alat dan bahan yang digunakan untuk memenuhi kebutuhan dalam pembuatan sistem. Adapun deskripsi alat dan bahan-bahan sebagai berikut :

Alat yang digunakan meliputi :

1. Personal Computer (PC).

2. Solder timah.

3. Software Fritzing

4. Software Arduino 1.8.0

5. Arduino Uno sebagai bootloader untuk upload program

6. Smartphone Android

Sedangkan bahan-bahan yang digunakan :

1. Mikrokontroller ATmega328

2. Sensor Warna.

3. Motor servo standar.

4. IC regulator (LM7805, LM7806)

5. Lampu led . 
6. Jack baterai.

7. Timah solder

\section{Rangkain Bluetooth HC-05}

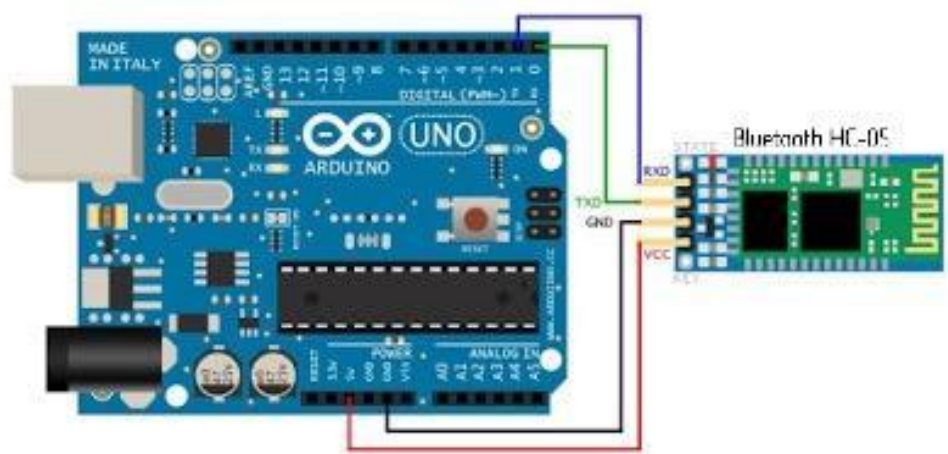

Gambar 3. Rangkaian Bluetooth HC-05

Modul bluetooth serial, yang selanjutnya disebut dengan modul BT saja digunakan untuk mengirimkan data serial TTL via bluetooth. Modul BT ini terdiri dari dua jenis yaitu Master dan Slave. Modul bluetooth ini berguna untuk menghubungkan robot dengan smartphone sehingga adanya interaksi ketika sebuah benda di temukan Jika sistem mikrokontroler dipasangi modul BT Slave maka ia dapat berkomunikasi dengan perangkat lain semisal PC yang dilengkapi adapter BT ataupun dengan perangkat ponsel, smartphone dan lain-lain, tentunya sistem mikrokontroler yang dilengkapi dengan BT Master dapat bekerja mengakses device-device tersebut. Dan berikut konfigurasi sensor bluetooth:

while (Serial.available())\{

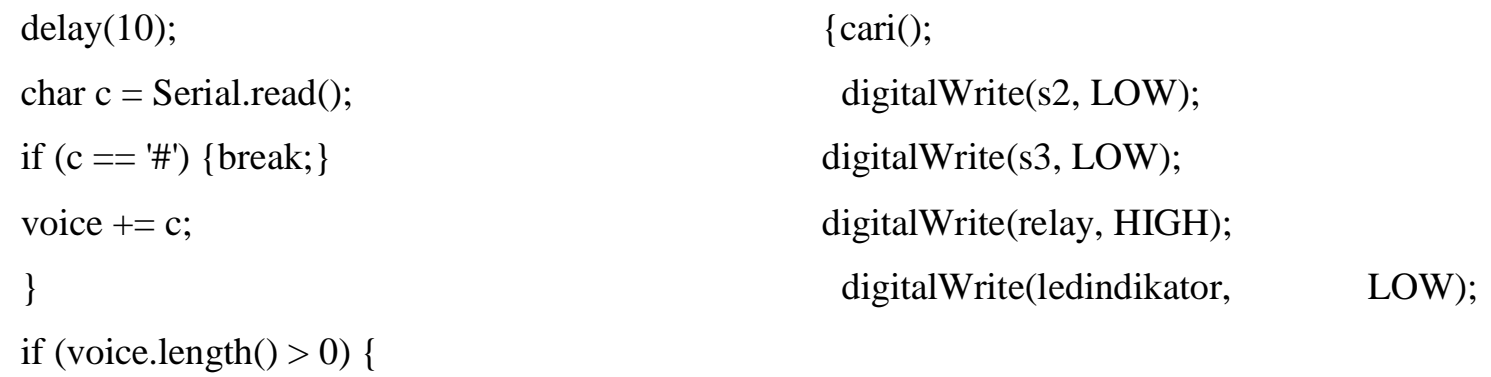

Serial.println(voice);

$$
\text { if }(\text { voice }==\text { "*jalan") }
$$

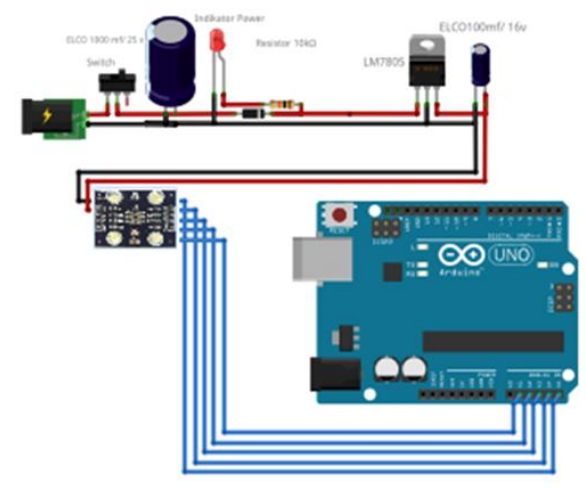

Gambar 4. Rangkaian Sensor Warna 
Sensor warna yang sering digunakan pada aplikasi mikrokontroler untuk pendeteksian suatu object benda atau warna dari objet yang di monitor. Sensor warna TCS230 juga dapat digunakan sebagi sensor gerak, dimana sensor mendeteksi gerakan suatu object berdasarkan perubahan warna yang diterima oleh sensor. Pada dasarnya sensor warna TCS230 adalah rangkaian photo dioda yang disusun secara matrik array $8 \times 8$ dengan 16 buah konfigurasi photodioda yang berfungsi sebagai filter warna merah, 16 photodiode sebagai filter warna biru dan 16 photo dioda lagi tanpa filter warna. Sensor warna TCS230 merupakan sensor yang dikemas dalam chip DIP 8 pin dengan bagian muka transparan sebagai tempat menerima intensitas cahaya yang berwarna. Dan berikut konfigurasi sensor warna:

color();

if (red < blue \&\& red < green \&\& red < 20)

\{

//Serial.println("SUDAH KETEMU");

digitalWrite(motor1Pin1, LOW); digitalWrite(motor1Pin2, LOW); digitalWrite(motor2Pin1, LOW); digitalWrite(motor2Pin2, LOW); digitalWrite(relay, LOW);

digitalWrite(ledindikator, HIGH); //

// delay(10);

\}

else if (blue < red \&\& blue < green)

\{

// Serial.println(" - (Blue Color)");

//digitalWrite(ledindikator, LOW);

\}

\section{Rangkaian Sistem Keseluruhan}

Setelah melakukan perancangan perangkat keras dari seluruh komponen dan bahan yang digunakan, maka rangkaian sistem keseluruhan akan terlihat seperti berikut :

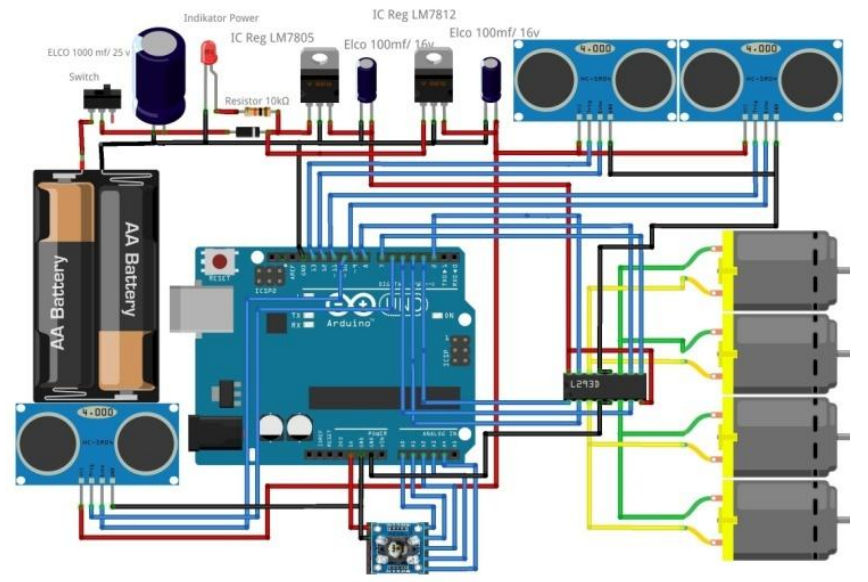

Gambar 5. Rangkaian Keseluruhan

\subsection{Implementasi Dan Cara Kerja Alat}

Berdasarkan cara kerjanya, dan Pengendalian Robot pencari benda ini dibuat untuk memonitoring sekaligus mendeteksi benda secara otomatis, adapun cara kerja alat ini yang akan dijelaskan berdasarkan Input, Proses dan Ouput sebagai berikut :

a. Input 
Pada alat Monitoring dan Pengendalian robot pencari benda ini terdapat 1 sensor yang menjadi alat ini input yaitu Sensor warna yang berfungsi sebagai pendeteksi obyek benda dengan jarak yang dapat dijangkau sekitar 3-70 cm, Sensor warna pada dasarnya sama dengan cara kerja sensor pada umumnya namun pebedaan cara kerja pada sensor warna ini dapat dilihat secara langsung pada bagian sensor membaca sebuah benda dengan mendeteksi sebuah warna benda tersebut.

\section{b. Proses}

Pada dasarnya yang harus dilakukan pada alat ini ialah dengan menentukan berapa jarak benda yang bisa di deteksi oleh sensor warna, dimana benda tersebut tentunya harus sesuai dengan keinginan, Dalam menentukan jarak tersebut dapat diatur dengan menggunakan software arduino yang nantinya akan terprogram pada alat monitoring dan pengedalian robot tersebut. Robot pencari benda tersebut diletakan pada sebuah ruangan, karna cara kerja alat ini terfokus pada sensor sebagai alat pendeteksi benda pada ruangan, Dimana apabila ada benda yang tidak ditemukan oleh manusia maka sensor benda bisa mendeteksi benda menurut jenis warna benda tersebut dan akan bekerja secara otomatis mencari benda dengan sendirinya.

c. Output

Setelah proses pengambilan data dari sensor tersebut maka data keluaran akan langsung dikirimkan ke sebuah perangkat android melalui media bluetooth yang tersambung dengan Robot Pencari Benda tersebut, Perangkat android tersebut berfungsi sebagai penggerak alat Monitoring dan Pengendalian.

\subsection{Pengujian Jarak Deteksi Benda}

Pengujian jarak dalam pendeteksian benda dilakukan dengan cara menempatkan benda pada jarak yang ditentukan. Kemudian pada console akan didapatkan nilai parameter $\mathrm{x}, \mathrm{y}$, dan radius yaitu titik tengah dan radius benda yang terdeteksi. Dengan melihat hasil pendeteksian benda pada setiap frame tersebut, maka dapat disimpulkan pada jarak tertentu apakah aplikasi dapat mendeteksi benda. Berikut adalah hasil pengujianTabel Pengujian Intensitas sensor pada cahaya :

Tabel 1. Pengujian Jarak Deteksi Benda

\begin{tabular}{|c|c|c|c|c|}
\hline Pengujian & Jarak(cm) & $\mathbf{x}$ & $\mathbf{y}$ & Radius \\
\hline 1 & 20 & 162 & 182 & 44.6878 \\
\hline 2 & 30 & 166 & 140 & 37.3363 \\
\hline 3 & 50 & 165 & 102 & 21.0950 \\
\hline 4 & 100 & 168 & 68 & 13.0000 \\
\hline 5 & 150 & 164 & 48 & 9.4339 \\
\hline 6 & 200 & 162 & 40 & 7,2801 \\
\hline
\end{tabular}

\subsection{Sistem Kerja}

Robot pencari benda memiliki kemampuan untuk mengolah data visual dari objek yang ditangkapnya dengan menggunakan sensor warna. Sensor warna dirancang dan diprogram untuk mengenali warna suatu objek. Robot pencari benda ini menitikberatkan pada materi penggunaan sensor warna TCS230 sebagai mata robot. Robot pencari benda ini mempunyai sistem yang dapat dibagi ke dalam 3 kelompok yaitu: 1 . Sensor vision robot yaitu sensor warna TCS230 
yang di perintahkan dengan suara si pengguna. Sistem kerja dari robot pencari benda ini adalah sensor warna menangkap warna dari obyek tersebut yang di kendalikan melalui smartphone dan menghasilkan signal dari obyek tersebut. Signal tersebut selanjutnya diproses dalam arduino menjadi data digital untuk dikirimkan ke smartphone untuk mengetahui benda tersebut sudah ditemukan.

\section{Pemetaan Daerah Sistem Penginderaan Robot}

Rancangan tata letak pengindera sensor warna depan dan samping serta jangkauan sensor pada robot. Pengindera inframerah depan mempunyai 4 resolusi jarak diskret. Keberadaan obyekbenda dapat di prediksi pada ke empat level jarak tersebut sehingga dapat ditentukan kecepatan dan patern gerakan robot. Tidak hanya dapat mengetahui ada atau tidaknya obyek penghalang, tetapi dari sisi depan, robot mempunyai kemampuan memprediksi letak penghalang pada 4 level jarak.

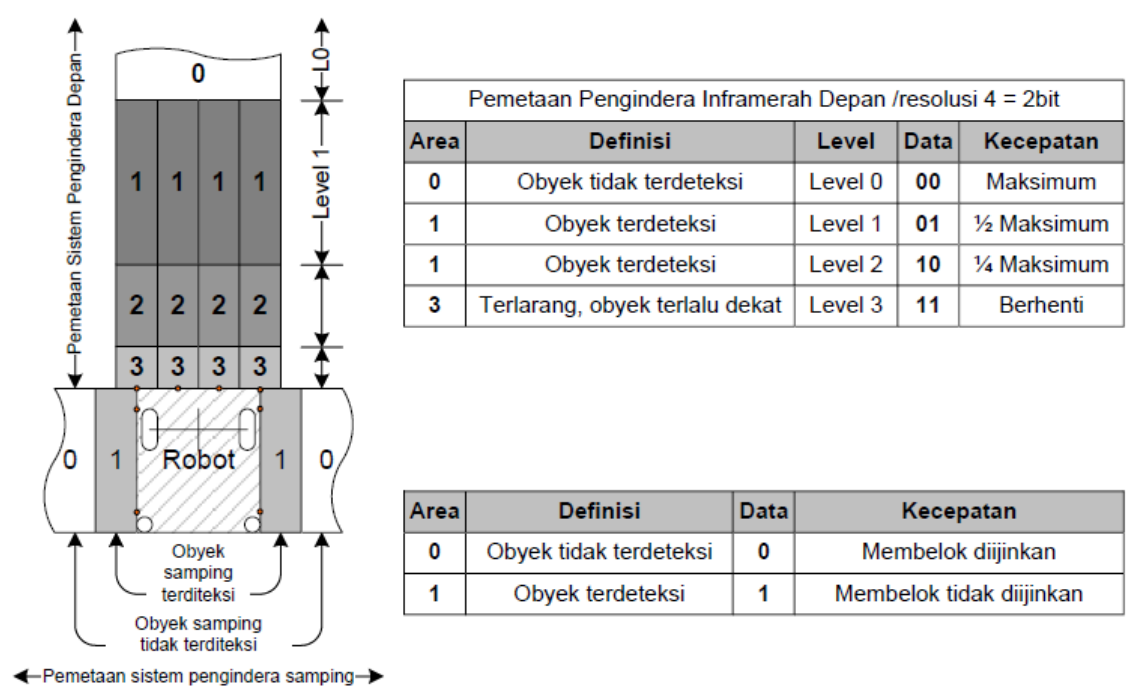

Gambar 6. Pemetaan Sistem Penginderaan Robot sumber: (Majalah Ilmiah UKRIM Vol. 07, No. 01, Januari 2015)

\section{KESIMPULAN DAN SARAN}

Dari hasil penulisan dan perancangan robot pencari benda menggunakan perintah suara berbasis arduino uno dapat diambil beberapa kesimpulan, diantaranya:

1. Membantu manusia dalam hal mencari benda yang hilang atau terselip di suatu tempat dengan mengenali warna objek benda tersebut, maka robot tersebut akan bergerak sendirinya.

2. Aplikasi sudah dapat mengintegrasikan Robotin dengan PC melalui jaringan bluetooth.

3. Robot dapat mendeteksi warna benda dengan menggunakan warna HSV yang selanjutnya digunakan untuk proses color filtering.

4. Menciptakan robot yang jika berdekatan dengan sebuah benda maka sensor warna akan mendeteksi warna pada benda tersebut apakah warna sudah sesuai atau belum, jika warna belum sesuai maka robot akan putar kanan dan kembali sampai mendapat warna yang diinginkan. dengan menghasilkan output tampilan dan notifikasi melalui smartphone.

5. Jarak robot terhadap benda adalah pada level jarak terdekatnya semakin jauh dari benda maka sensor led tidak akan menyala, sebaliknya jika dekat dengan benda maka notif akan dikirim melalui smartphone. Jarak memerlukan akurasi lebih tinggi dibanding daerah yang tidak kritis, sehingga dipakai pemetaan relatif yang membutuhkan data yang lengkap. 


\section{DAFTAR PUSTAKA}

[1]. Roni Setiawan. (2012). "Robot Pendeteksi Objek Berdasarkan Warna Dengan Sensor Kamera Sebagai Media Pembelajaran”. Tugas Akhir. Universitas Negeri Yogyakarta.

[2]. Rendy Dartha Nugraha. (2016). "Rancang Bangun Mobile Robot Pengikut Manusia Berdasakan Warna Menggunakan Metode Template Matching Berbasis Mini PC”. Jurnal Sains dan Teknologi 2016 p-ISSN : 2407 - 1846. Universitas Andalas

[3]. Anis Zaenal Abidin. (2011). "Pengendalian Robot Mobil Pencari Target Dan Penghindar Rintangan Dengan Metode Kontrol PD Menggunakan Mikrokontroler AVR Atmega 8535". Jurnal. Jurusan Teknik Elektro Fakultas Teknik Universitas

[4]. Siti Nurmaini. (2012). "Modeling of Mobile Robot System with Control Strategy Based Diponegoro Semarang.on Type-2 Fuzzy Logic”. Volume 2 No. 3, March 2012 ISSN 22234985, Computer Engineering Department, Faculty of Computer Science, Sriwijaya University

[5]. Agung Alpurqon.(2014). Sistem Pengendali Pintu Pagar Secara Otomatis Menggunakan Aplikasi Voice Command Pada Smartphone Android OS. Tugas Akhir. Perguruan Tinggi Raharja.

[6]. Gogor C. Setyawan. (2015). "Sistem Robot Otonom Penghindar Rintangan dan Pencari Jalur Menuju Sasaran Berbasis Mikrokontroler PIC16F877A". Jurnal. Teknik Informatika, Fakultas Sains dan Komputer, Universitas Kristen Immanuel.

[7]. Yustinus Pancasila Prayitno (2012). "Rancang Bangun Bentuk Aplikasi Pendeteksi Bentuk Dan Warna Benda Pada Mobile Robot Berbasis Webcam". Jurnal. Jurusan Sistem Komputer, STIKOM Surabaya.

[8]. Ratnasari Nur Rohmah (2016)."Rancang Bangun Robot Beroda dengan Object Tracking Sebagai Dasar Pengendalian Gerakan Robot". Jurnal PROtek Vol. 03 No. 1, September 2016. Teknik Elektro, Universitas Muhammadiyah Surakarta.

[9]. Fajar Timang Patiung (2013). "Rancang Bangun Robot Beroda dengan Pengendali Suara". e-journal Teknik Elektro dan Komputer (2013). Jurusan Teknik Elektro-FT, UNSRAT, Manado.

[10].Rudy Dikairono (2013). "Sistem Navigasi Dan Penghindar Rintangan Pada Mobile Robot Menggunakan GPS Dan Pengukur Jarak Ultrasonik". JAVA Journal of Electrical and Electronics Engineering Volume 11, 2013. Jurusan Teknik Elektro Institut Teknologi Sepuluh Nopember (ITS) Surabaya, Indonesia. 